\title{
Metastatic Lymphoma of the Paranasal Sinuses
}

\author{
Pooja Ravindra and Borligegowda Viswanatha* \\ Otorhinolaryngology department, Bangalore medical college \& research institute, India
}

Submission: June 23, 2018; Published: July 16, 2018

*Corresponding author: BorligegowdaViswanatha,Professor of ENT,Bangalore medical college \& research institute, Bangalore, India, Tel: 919845942832; Email: drbviswanatha@yahoo.co.in

\begin{abstract}
In the paranasal sinuses, a metastatic tumor is far less common than primary tumor. Metastasis of penile lymphoma to the paranasal sinuses is very rare. The authors describes a case penile Non Hodgkin's lymphoma that metastasized to the paranasal sinuses in a 60-year-old man. The patient was treated with chemo - radiotherapy but was lost to follow-up after 3 months.
\end{abstract}

\section{Introduction}

Paranasal sinus malignancies represents a small portion of the head and neck malignancies, approximately $5 \%$ of all head and neck tumors [1].Metastatic tumors of the paranasal sinuses are much less common [2]. In a review of the world literature published in 2001, Prescher and Brors found 123 reports of 169 cases of metastatic carcinoma of the paranasal sinuses [3].In this article, we are reporting a rare case of a patient with distant metastasis of Non Hodgkin's lymphoma into the paranasal sinuses from the penis.

\section{Keywords: Metastatic; Lymphoma; Nose}

\section{Case Report}

A 60yr old male patient presented with complaints of swelling over the penis from 2 months for which the patient underwent debridement and incisional biopsy. Examination showed swollen and inflamed glans with multiple openings and slough over it. Corpora spongiosa, corpora cavernosa and proximal penile shaft appeared normal. Biopsy of the lesion, on histopathological examination revealed $\mathrm{T}$ cell nonHodgkin's lymphoma (Figure 1). The patient was referred to the otolaryngology department with the complaints of bilateral nasal obstruction, epistaxis and severe frontal headache. Diagnostic nasal endoscopy showed a fleshy friable mass occupying bilateral nasal cavities up to the vestibule. Next day patient developed rapidly progressive proptosis and loss of vision in both the eyes. Emergency Ophthalmology consultation was taken. Fundoscopic examination revealed progressive central retinal artery occlusion.A contrast enhanced CT scan and MRI of the paranasal sinuses and orbits was performed. It showed soft tissue lesion completely filling bilateral frontal, ethmoidal, maxillary, sphenoid sinuses. Widening of ethmoidal infundibulum and erosion of bilateral turbinates. The lesion had eroded the posterior wall of left maxillary sinus and extending to the infra-temporal fossa. The lesion had eroded the lamina papyracea on both the sides and extending into the orbit (Figure 2).

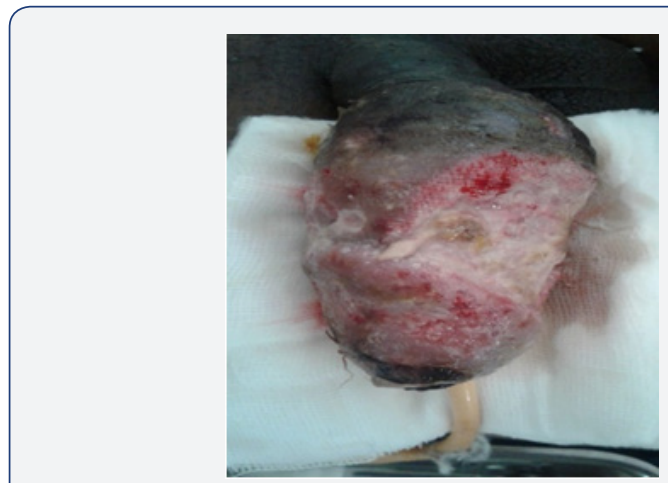

Figure 1: Photograph showing swollen and inflamed glans.

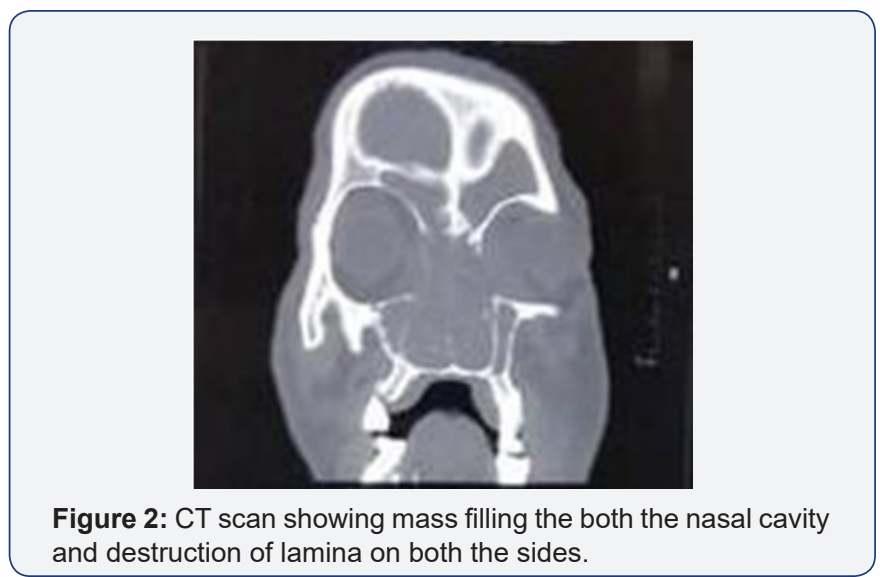




\section{Global Journal of Otolaryngology}

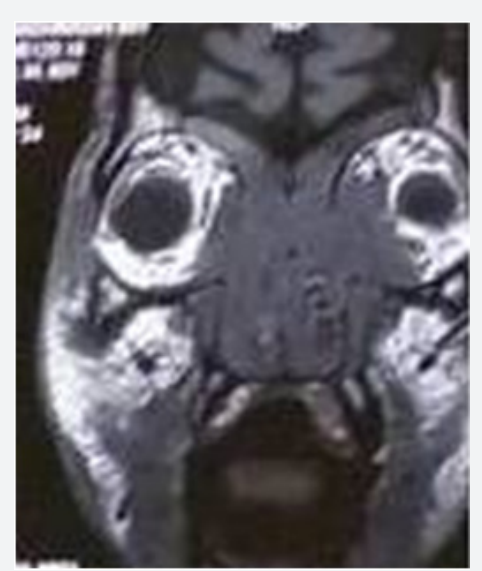

Figure 3: MRI scan showing mass filling the both the nasa cavity with extension into the orbit both the sides.

MRI scan showed soft tissue attenuation involving bilateral nasal cavities, maxillary, ethmoidal, sphenoidal sinuses with involvement of the medial aspect of bilateral orbit with infiltration of left medial and inferior recti and inferior oblique muscle (Figure 3).Nasal mass biopsy was done. Histopathological examination showed tissue fragments lined by respiratory epithelium exhibiting areas of ulceration with an underlying tumor composed of atypical lymphoid cells which are arranged in diffuse sheets and clusters. These lymphoid cells are intermediate sized and showed large hyper chromatic nucleus with scanty eosinophilic cytoplasm and are mitotically active (Figure 4).The histopathological picture was suggestive of Non Hodgkin's Lymphoma.The patient was referred to the Oncology department for further management. The patient was treated with chemo - radiotherapy but was lost to follow-up after 3 months.

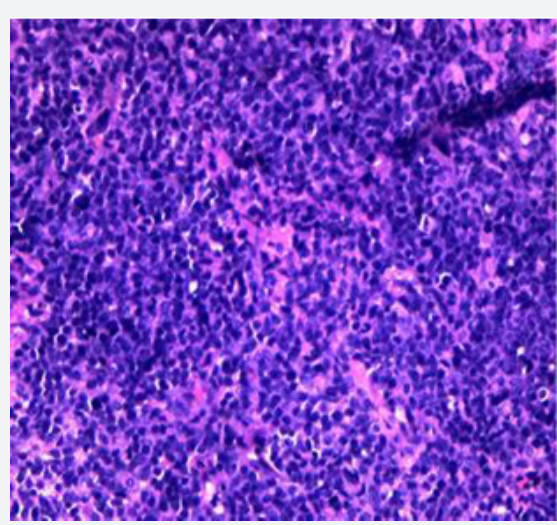

Figure 4: Microphotograpgh showing large hyper chromatic nucleus with scanty eosinophilic cytoplasm.

\section{Discussion}

Paranasal sinuses are a complex anatomic area, surrounding important structures such as the orbit and skull base. The most incident tumours are the squamous cell carcinoma, followed by adenocarcinoma and adenoid cystic carcinoma [4].In a review, Prescher and Brors reported 169 cases of metastatic tumour to the paranasal sinuses [3]. Most cases originated from the kidney, followed by the lung, breast, thyroid, and prostate. Prescher and Brors also reported that the maxillary sinus was the most affected, followed by the sphenoid, ethmoid, and frontal sinuses $[3,5]$. These data are similar to those published by Bernstein [6]. The nasal symptoms are usually nasal mass, nasal obstruction, facial deformity, and epistaxis. Orbital symptoms may also occur, such as proptosis, ptosis, decreased vision, and diplopia. Occasionally, these symptoms may be the first presentation of an occult primary tumor[7,8].Metastasis may reach the paranasal sinuses by hematogenous, lymphogenous, or vertebral venous plexus pathways. First postulated by Batson [9], this low-pressure valve less system is a connection between deep pelvic veins, intercostal veins, vena cava, and the azygos system. A rise in the abdominal pressure might redirect the blood flux from the vena cava system to the vertebral venous plexus. This flux alteration can allow the tumor to reach the paranasal sinuses [10].Imaging is essential to determine location and extension of the lesion and for surgical planning. CT may show enhancement, bone erosion, remodeling, and invasion. Magnetic resonance imaging (MRI) has an important role to help, defining leptomeningeal and orbital invasion [9].Studies have shown that with the combined treatment of chemotherapy and local radiation, patients with lymphoma of the nasal cavity and paranasal sinuses have a better prognosis [11,12]. Early diagnosis and staging are essential for effective treatment, and lymphomas must always be included in the differential diagnosis of lesions of the nasal cavity and paranasal sinuses.

\section{References}

1. Bossi P, Farina D, Gatta G, Lombardi D, Nicolai P, et al. (2016) Paranasal sinus cancer. Critical Reviews in Oncology/Hematology 98: 45-61.

2. Nelson EG, Goldman ME, Hemmati M (1990) Metastatic carcinoma of the ethmoid sinus. Otolaryngol Head Neck Surg 103(1): 120-123.

3. Prescher A, Brors D (2001) Metastases to the paranasal sinuses: Case report and review of the literature \&lsqb;in German\&rsqb. Laryngorhinootologie 80(10): 583-594.

4. Lund VJ, Stammberger H, Nicolai P, Castelnuovo P, Beal T, et al. (2010) European position paper on endoscopic management of tumours of the nose, paranasal sinuses and skull base. Rhinology Supplement 22(1): 1-143.

5. Viswanatha B (2008) Prostatic carcinoma metastatic to paranasal sinuses: A case report Ear Nose Throat J 87(9): 519-520.

6. Bernstein JM, Montgomery WW, Balogh K (1966) Metastatic tumors to the maxilla, nose, and paranasal sinuses. Laryngoscope 76(4): 621650 .

7. Oliver VJ, Valdés AL, Morillo, Ruiz del Portal JM, Conde Jiménez M, et al. (2001) Frontal ethmoid metastases of prostatic carcinoma. Report of one case and review of the literature. Acta Otorrinolaringológica Española 52(2): 151-154.

8. Lee M, Kim YM, Kim BM (2016) Epistaxis as the first manifestation of silent renal cell carcinoma: a case report with relevant literature review. Iran Journal of Radiology 13(1): e31208.

9. Batson OV (1940) The function of the vertebral veins and their role in the spread of metastases. Ann Surg 112(1): 138-149. 
10. Lopéz F, Devaney KO, Hanna EY, A Rinaldo, Ferlito A (2016)Metastases to nasal cavity and paranasal sinuses. Head and Neck 38(12): 18471854.

11. Shohat I, Berkowicz M, Dori S, Horowitz Z, Wolf M, et al. (2004) Primary non-Hodgkin's lymphoma of the sinonasal tract. Oral Surg Oral Med Oral Pathol 97: 328-331.
12. Longsdon M, Ha C, Kavadi V, Cabanillas F, Hess M, et al. (1997) Lymphoma of the nasal cavity and paranasal sinuses. Improved outcome and altered prognostic factors with combined modality therapy. Cancer 80: 477-488.

\section{Your next submission with Juniper Publishers} will reach you the below assets

- Quality Editorial service

- Swift Peer Review

- Reprints availability

- E-prints Service

- Manuscript Podcast for convenient understanding

- Global attainment for your research

- Manuscript accessibility in different formats ( Pdf, E-pub, Full Text, Audio)

- Unceasing customer service

Track the below URL for one-step submission https://juniperpublishers.com/online-submission.php 